\section{Clarifying Affiliations of Salix gracilistyla Miq. Cultivars and Hybrids}

\author{
Yulia A. Kuzovkina ${ }^{1}$ \\ Department of Plant Science and Landscape Architecture, Unit-4067, \\ University of Connecticut, Storrs, CT 06269-4067
}

Michael Dodge

Vermont Willow Nursery, 1943 Ridge Road North, Fairfield, VT 05455-5631

Irina V. Belyaeva

Royal Botanic Garden, Kew, Richmond, TW9 3AE, UK

Additional index words. Salix gracilistyla, Salix chaenomeloides, willow, nomenclature, japanese pussy willow, cultivar, asian pussy willow

\begin{abstract}
Salix gracilistyla Miq., japanese pussy willow or rosegold willow, is an ornamental shrub commonly cultivated for its prominent display of catkins in early spring. Verification of stocks of willows in the North American landscape nursery trade revealed that another name-Salix chaenomeloides Kimura-is associated frequently with plants similar to S. gracilistyla. Morphological analyses conducted during this study have shown that the $S$. chaenomeloides binomial is misapplied often to $S$. gracilistyla, its cultivars and hybrids. A comparison of the diagnostic characters of $S$. gracilistyla and $S$. chaenomeloides is presented to explain the differences between these taxa and to promote the adoption of the correct names. Five cultivars of $\boldsymbol{S}$. gracilistyla valued for their early spring catkin displays, variegated foliage, and pendulous habits, and two cultivars of a hybrid origin are summarized. Also, two new ornamental cultivars called Salix 'Winter Glory' and Salix 'Rabbit's Foot' are described.
\end{abstract}

Willows (Salix L.) are grown widely in many temperate countries because of their notable characteristics that include rapid growth rate, ornamental appearance, and easy vegetative propagation (Dickmann and Kuzovkina, 2014). Salix gracilistyla Miq., japanese pussy willow or rosegold willow, is an ornamental willow commonly found in the nursery trade. It is cultivated for its graceful arching habit and

Received for publication 4 Dec. 2015. Accepted for publication 15 Feb. 2016.

We thank Leen Leus, Plant Science Unit at the Institute for Agricultural and Fisheries Research, Belgium, for analyzing the DNA content; Cynthia Jones, University of Connecticut and Bill Hendricks, Klyn Nursery, for photography assistance; Chiara Nepi and Egildo Luccioli from the Herbarium Universitatis Florentinae, Italy (FI) and Christel Schollaardt from the Naturalis Biodiversity Center, Leiden, Netherlands (NHM), for assistance with herbarium specimens; Barry Yinger, Conard Pyle Star Roses; Stefan Lura, U.S. National Arboretum; Wayne Mezitt, Weston Nurseries; Michael Dirr, University of Georgia; Gary Koller, Koller and Associates; Rick Darke, Rick Darke LLC; Paul Meyer, Morris Arboretum, for historical information; Tim Wood, Spring Meadow Nursery; Dave Reed, Meadows Farm Landscaping, Virginia; Tapani Uronen, Salicetum Vainionranta (Finland); Shu Suehiro (http://www.botanic.jp/contents/zx.htm) Japan, for taxonomic information; Ethan Johnson, Holden Arboretum; Irina Kadis, Arnold Arboretum, for retrieving documents and preparing voucher specimens. We thank anonymous reviewers for their helpful comments and suggestions.

${ }^{1}$ Corresponding author. E-mail: jkuzovkina@, uconn.edu. outstanding early spring display of catkins emerging from large buds (Fig. 1). willows revealed that another name $-S$. chaenomeloides Kimura with the common names "giant pussy willow" or "asian pussy willow," became attached to the morphologically similar plants labeled as S. gracilistyla, and are found frequently in the catalogues of many North American growers. For example, the Plant Information Online database (2015) that lists sources of plants in North American nurseries, reported that $S$. chaenomeloides was available from 18 nurseries, eight of which are wholesale sellers. In contrast, $S$. chaenomeloides was not mentioned in the major U.K. database related to the plant trade (Royal Horticultural Society Plant Finder, 2015), and no evidence of the name or species availability in continental Europe was recorded.

To verify plant identity, fourteen accessions of these two species were procured from North American nurseries, botanic gardens, and private collections between 1999 and 2015. Plant identification was based on observations of the specimens through different phenological stages and by cross-checking with the original taxonomical treatments and some type specimens. It was confirmed that misapplication of the name $S$. chaenomeloides took place in many cases. There was considerable misuse of the names, as almost all accessions listed as $S$. chaenomeloides are indeed $S$. gracilistyla or its hybrids. Only one accession of $S$. chaenomeloides that was received in 1999 from Holden Arboretum, IL (No 81-604-88 1981 as Salix cf. glandulosa Seemen; wild collected
Observations of nursery stock offerings of in Korea) was confirmed as $S$. chaenomeloides. This accession was introduced by Peter Bristol of Holden Arboretum and Paul W. Meyer of Morris Arboretum. The cuttings were taken from a plant at the Chollipo Arboretum in South Korea on 7 Oct. 1981. The parent plant was "collected from the wild in nearby hills" (Paul W. Meyer, personal communication, Dec. 2015).

These studies were based on information from the protologues, authentic herbarium specimens held in Harvard University Herbaria, U.S. (A), Herbarium Universitatis Florentinae, Italy (FI), Royal Botanic Gardens Kew, UK (K), Main Botanical Garden, Russia (MHA), Naturalis Biodiversity Center, Leiden, Netherlands (NHM), and Muséum National d'Histoire Naturelle, France (P) (herbarium acronyms (Thiers, 2013). Nomenclature and a comparison of the two species are presented below. Accepted names are given in bold. Typification was made according to the International Code of Nomenclature for algae, fungi, and plants (Melbourne Code) (McNeill et al., 2012). Our objective was to promote the correct usage of the scientific name $S$. gracilistyla and to discontinue the misapplication of the name $S$. chaenomeloides within the community of willow growers and authors of plant cataloging.

\section{Historical Application}

Most horticultural references from the 20th and 21st centuries (Bailey, 1924; Bailey and Bailey, 1976; Bean, 1981; Hillier, 2014; Krussmann, 1978, 1984; Rehder, 1927, 1940, 1949; Walter et al., 1989) did not list $S$. chaenomeloides among cultivated plants. The first reference to this species in cultivation was found in the specialized volume "Willows: the Genus Salix" by Newsholme (1992) which is commonly used by practical horticulturists and nursery professionals. The description of S. chaenomeloides in this book was found to be inaccurate as it fits with most characters of $S$. gracilistyla, but not $S$. chaenomeloides. The monochromatic drawing and the color picture displayed by Newsholme (1992: p. 62, Fig. 22 and plate 19) are both labeled $S$. chaenomeloides, but have illustrated $S$. gracilistyla instead. Tapani Uronen from Salicetum Vainionranta (Finland) received a plant named $S$. chaenomeloides from Newsholme's collection and noted that this clone did not have the characteristics of this species. Uronen called this plant "western S. chaenomeloides" or "red bud pussy willow" suggesting that it is probably "a hybrid which is very closely related to $S$. gracilistyla" (Uronen, 2004; T. Uronen, personal communication, Sept. 2015).

The name $S$. chaenomeloides appeared in the two most recent editions of the authoritative U.S. manual by Dirr (1998, 2009); however, this species was not listed in previous editions. Also, the description of $S$. chaenomeloides in this volume was erroneous and fits $S$. gracilistyla, not $S$. chaenomeloides. Consequently, misuse of the name $S$. chaenomeloides was found in scientific publications and extension materials in North America throughout the last 20 years (Armitage and Dirr, 1995; Greer 

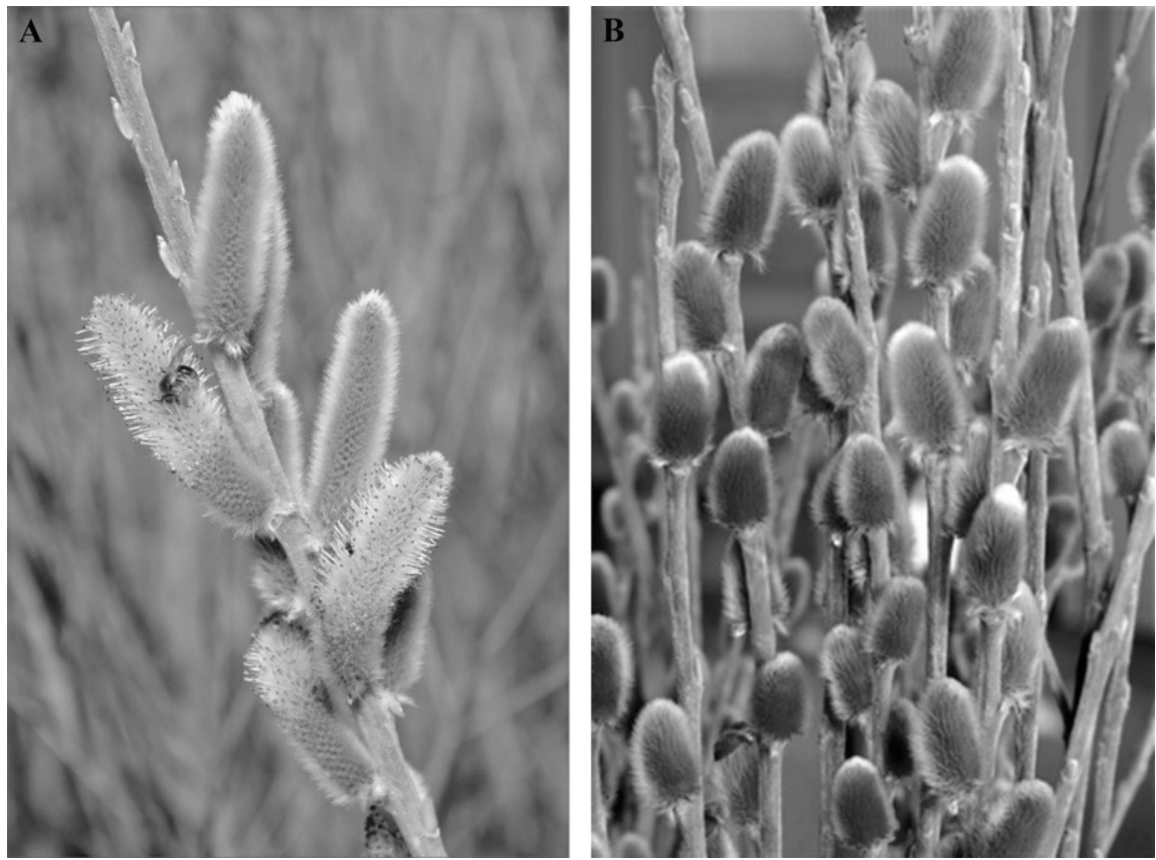

Fig. 1. (Left) Salix gracilistyla Miq., japanese pussy willow, during anthesis; (right) S. gracilistyla Miq 'Mt. Aso' after inflorescence expansion. Photos by M. Dodge.

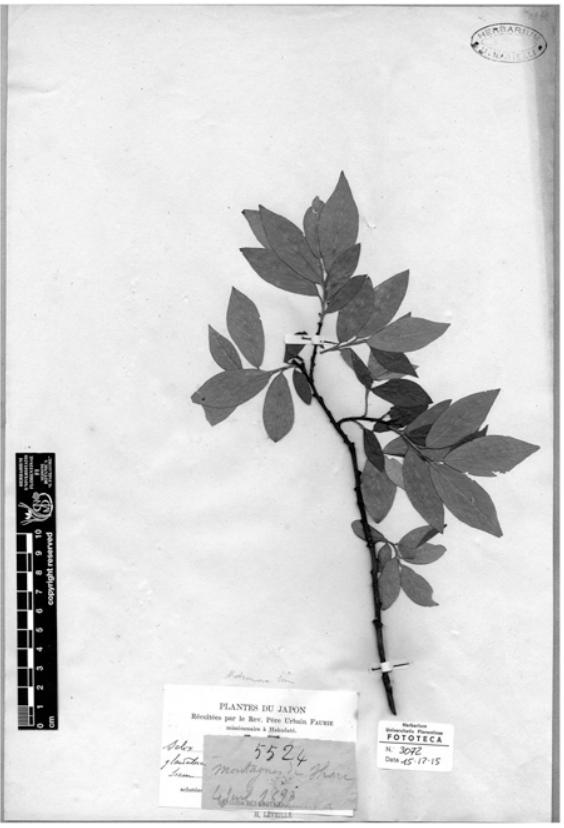

Fig. 2. A herbarium specimen of Salix $\times$ leucopithecia Kimura from the Herbarium Universitatis Florentinae, Italy, incorrectly identified as Salix chaenomeloides Kimura (三Salix glandulosa Seemen).

and Dole, 2008; Saska et al., 2010) where descriptions demonstrate erroneous referral to S. gracilistyla.

It is uncertain why misuse of the name $S$. chaenomeloides occurred originally and what led to this misidentification, as $S$. chaenomeloides and $S$. gracilistyla are two unrelated and morphologically different species. A recently discovered herbarium specimen of $S$. ×leucopithecia Kimura from the Herbarium Universitatis Florentinae, Italy (FI), which was incorrectly identified as $S$. chaenomeloides ("Salix glandulosa Seem."), may have resulted in the original confusion (Fig. 2). This specimen was not mentioned by Seemen in his protologue, and it is not likely that the name on the label was written by Seemen. It is also possible that the erroneous description by Newsholme (1992) prompted the misuse of the name $S$. chaenomeloides among cultivated plants more than 20 years ago. Another possibility is that misidentification of plant material took place during its introduction from Asia, or that the plant was mislabeled at the source. Also, it is possible that the Asian sources adopted the erroneous European name for its native species. Interestingly, even Japanese gardening sites often use the irrelevant common name "japanese pussy willow" for their native $S$. chaenomeloides. However, catkins lack a "furry" appearance or "pussy willow" effect.

\section{Introduction to the United States}

Barry Yinger, a notable plantsman and plant explorer of Korea and Japan, brought back a hybrid of $S$. gracilistyla mistakenly named as $S$. chaenomeloides from Chollipo Arboretum, South Korea, in the early 1980s; Chollipo Arboretum first received this specimen from "someone in Europe" (Barry Yinger, personal communication, June 2015). After introducing Yinger's specimen labeled as S. chaenomeloides to the United States, it was distributed to Richard W. Lighty, Coordinator of Longwood Program and later Director of the Mt. Cuba Center. Then, cuttings were dispersed from there to Richard Schulhof, Deputy Director of the Arnold Arboretum at the time, who had an interest in willows, receiving the accession number "139-900-A." The purpose of the acquisition was stated as "Observation, Richard Schulhof" in the records of the Arnold
Arboretum. Next, this plant was distributed from the Arnold Arboretum in 1990 to the Holden Arboretum as accession $S$. chaenomeloides "90-248." Also, it is likely that the same plant was disseminated from the Arnold Arboretum to some U.S. nurseries (Wayne Mezitt and Gary Koller, personal communication, July 2015). This specimen at the Arnold Arboretum is still alive (Irina Kadis, personal communication, July 2015), but as of 17 June 2014 was labeled as in "fair condition; major stem canker; major deadwood; bracket fungi at $1.0 \mathrm{~m}$ to $2.0 \mathrm{~m}$; minor insect damage (chewed leaves)." The voucher specimen of this plant (No. 139-90-A, collection number 27-2015), collected on 18 July 2015, is deposited at the Herbarium of the Arnold Arboretum (A).

Michael Dirr noted that $S$. chaenomeloides was given to him by Don Shadow (Shadow Nursery, Inc., Winchester, TN) in early Feb. 1988, and planted at the University of Georgia Farm. However, it is possible that Don Shadow also received his specimen from Barry Yinger (Dirr, 2009; M. Dirr, personal communication, July 2015). These plants were used in cut-branch trials by Allan Armitage (Armitage and Dirr, 1995).

Another introduction of plants under the incorrect name $S$. chaenomeloides into North America took place during the 1985 Elite Plants Expedition to Japan, conducted by Sylvester (Skip) G. March of the U.S. National Arboretum and Frederick (Rick) P. Darke of Longwood Gardens. The overall purpose of the expedition was the collection of elite, largely cultivated, plants from Japanese sources for introduction as potential ornamentals in the United States, or for use in further breeding and selection work. A collection named S. chaenomeloides and numbered J-85-227 was made on 17 Nov. 1985 at Fujinami Nursery in Ishigami, Kawaguchi, Saitama Prefecture (Honshu), Japan. This material was accessioned at the U.S. National Arboretum as $S$. chaenomeloides (NA 57189) with the following collection description: "Fujinami Nursery, Ishigami, Kawaguchi, Japan. Bud scales turn red, swell, and partly exposed silky hairs of inflorescences by late autumn. Useful for cuttings and further forcing in fall. (donated). 11/17/85." There are three male plants alive from this original accession in the U.S. National Arboretum. It is possible that the U.S. National Arboretum or Longwood Gardens may have distributed material in the late 1980s or 1990s as well, and it is possible that the material was shared between these two institutions after the completion of the expedition (Stefan Lura, personal communication, Dec. 2015).

Therefore, that there were a few paths of distribution of a plant noted under the incorrect $S$. chaenomeloides name into North America, as a few distinct clones described in this article were obtained from some nurseries.

\section{Morphological Comparison of S. gracilistyla and $S$. chaenomeloides}

Confusion in willow species are usually associated with the inherent identification difficulties and the poor separation of taxonomic groups. 
However, morphological differences between $S$. chaenomeloides and $S$. gracilistyla are considerable. These two taxa represent systematically distant species with little morphological resemblance. For clarity, the unique characters of both species, based on authoritative taxonomic treatments, are described in Table 1.

\section{Taxonomy and Nomenclature}

Salix chaenomeloides Kimura, Sci. Rep. Tohoku Imp. Univ., Ser. 4, Biol. 13:77. $1938 \equiv$ S. glandulosa Seemen, Beibl. Bot. Jahrb. Syst. 53:55. 1896, nom. illeg. $\equiv$ Pleiarina glandulosa N.Chao \& G.T.Gong, J. Sichuan Forest. Sci. Technol.: 17(2): 4 (1996), nom.superfl.

Type. Japan Siebold, s.n. (lectotype, L, L0420288! - fragment with female catkins on the left, designated here by I.V. Belyaeva; syntypes B destroyed).

Information from the protologue: "In dem Herbar des Königl. Botanishen Museums zu Berlin befinden sich von dieser Weide männliche und weibliche Blütenzweige, die von Hilgendorf in Japan (ein genauer Standort ist nicht angegeben) gesammelt worden sind. Ausserdem liegt ein Blattzweig mit abgeblühten weiblichen Kätzchen aus dem Rijks-herbar in Leiden vor, welches von Siebold in Japan gesammelt (eine genauere Standsortsangabe fehlt auch hier) und von Miquel als Salix Buergeriana Miq. bestimmt ist (1. Herb. Ludg. Bat. Salix Buergeriana Miq. Japonia. Siebold. Determ. Miquel; Andersson vidit)."

Comments. Seemen, while describing $S$. glandulosa, a replaced synonym of $S$. chaenomeloides and homotypic to the latter, mentioned specimens that were stored at B and were consequently destroyed during the World War II. Also, a cited specimen at L, collected by Siebold in Japan, identified by Miquel as Salix buergeriana Miq. and seen by Andersson. This specimen, L0420288, which was located at L (Fig. 3), corresponds to the protologue and is a part of the original material. The original label on this herbarium sheet is the same as that cited in the protologue by Seemen. There are two fragments attached to the sheet that belong to $S$. chaenomeloides and probably were collected from the same individual. The fragment on the left with leaves and female catkins is selected here as the lectotype.

Vernacular names. Chinese "Xian liu"; Japanese "Maruba-yanagi" or "Akame-yanagi."

Classification. Salix chaenomeloides belongs to the subgenus Protitea Kimura, along with North American native Salix nigra Marshall and South American native Salix humboldtiana Willd. (Argus, 2010; Ohashi, 2000, 2001). In "Flora of China," this willow is placed in the section Wilsonia K. S. Hao (Fang et al., 1999). It is native to Japan, Korea, and China (Ohashi, 2000, 2001).

Salix gracilistyla Miq., Ann. Mus. Bot. Lugduno-Batavi. 3:26. $1867=$ S. thunbergiana Blume ex Andersson, Prodr. (A.P. de Candolle). 16(2):271. 1868.

Type. Japan, Nagasaki Oldham 527, 1862 (lectotype P, P00761026! - fragment with female catkins in the middle, designated here by I.V. Belyaeva; syntypes: P, P00761025!, NHN, L0040923!

Protologue. "Detexit Buerger, qui m. Martio sp. Masc. florentia legit, prope Nangasaki masc. et fem. Oldham (Salix n. 527)."

Table 1. Comparisons of the morphological characters of Salix gracilistyla and Salix chaenomeloides (based on Ohashi, 2001; Ohwi, 1965).

\begin{tabular}{|c|c|c|}
\hline Character & Salix gracilistyla Miq. & Salix chaenomeloides Kimura \\
\hline Habit & $\begin{array}{l}\text { Dense, abundantly branched shrub or } \\
\text { small tree up to } 3 \mathrm{~m} \text { tall }\end{array}$ & Tree up to $20 \mathrm{~m}$ tall \\
\hline Branches & $\begin{array}{l}\text { Rather thick erect branches; young } \\
\text { branchlets with dense, long, whitish pubescence }\end{array}$ & $\begin{array}{l}\text { Rather slender; geniculate; young branchlets } \\
\text { hairy, soon glabrate, yellowish }\end{array}$ \\
\hline Leaf blade & $\begin{array}{l}\text { 7-13 cm long, } 1.5-3 \mathrm{~cm} \text { wide; margin } \\
\text { serrulate or with small glands; upper } \\
\text { surface sericeous, glabrescent; lower } \\
\text { surface densely appressed, grayish } \\
\text { white, sericeous }\end{array}$ & $\begin{array}{l}5-12 \mathrm{~cm} \text { long, } 2-6 \mathrm{~cm} \text { wide; margin serrate with } \\
\text { incurved teeth; upper surface glabrous and } \\
\text { brownish-red when young, becoming glaucous, } \\
\text { glabrous and slightly pubescent only near base } \\
\text { beneath (Fig. 4). Glands appear on the proximal edges }\end{array}$ \\
\hline Leaf venation & $\begin{array}{l}\text { Lateral nerves strictly parallel and } \\
\text { prominent, } 14-18 \text { pairs, with appressed }\end{array}$ & $\begin{array}{l}\text { Lateral nerves not parallel, rather prominent on } \\
\text { both sides; } 12-14 \text { pairs }\end{array}$ \\
\hline
\end{tabular}

Stipules

Petiole

Phenology

Inflorescences

Bracts

Nectaries long, staist, 18 pairs, with appr characteristic for this species, branching nearly patent from midrib. Looped within the margin

Stipules oblique ovate, up to $1 \mathrm{~cm}$ long

Petiole $0.5-2 \mathrm{~cm}$ long, densely pubescent

Precocious: flowers before leaves emerge in early March to late April

Terete densely flowered; male is $3-4 \mathrm{~cm}$ long, $1-1.2 \mathrm{~cm}$ across; female is $2-5 \mathrm{~cm}$ long, $1-1.5 \mathrm{~cm}$ in diameter. Flowering branchlets absent or very short, sometimes with one or two small leaves

Ovate, 3-4 mm long, tricolored: upper part black, middle part red, base pale yellowish green, both surfaces with dense, long hair; apex acuminate

Stamens

$$
1 \text {, adaxial }
$$

2 filaments, fully connate, glabrous; anthers reddish

Ovary

Chromosome no.
Stipules conspicuous, flabellate, oblique ovate to orbicular or reniform, up to $1.3 \mathrm{~cm}$ long or $1.5 \mathrm{~cm}$ broad, serrulate, with a gland at tip of teeth

Petiole (0.3)0.5-1.2 cm long, with a small discoid gland near apex on each side and in the center. Developing leaves and petioles are red

Coetaneous: flowering and leaf emergence takes place simultaneously, in April to early May

Rather loosely flowered; $2-7 \mathrm{~cm}$ long in flower, $6-10 \mathrm{~cm}$ long in fruit. Flowering branchlets with several small leaves

Male bracts obovate, $\approx 2.5 \mathrm{~mm}$ long; female bracts deciduous obovate-orbicular, ca. $1.5 \mathrm{~mm}$ long, concolorous, yellowish green, abaxial surface short, pubescent, dimorphic

2 , dorsiventral, usually at the base forming a nearly lobed false disc

(3)4-5 filaments, free, pubescent at the base; anthers yellow

Narrowly ovoid, stipulate, patent, glabrous; stigmas minute, bifid on very short styles or sessile $2 n=38$ 
Comments. Three specimens have been located, one in L (L0040923) and two in P (P, P00761025 and P00761026, that were mentioned in the protologue, corresponding to Miquel's description and belonging to the original material. The specimen at NHN L0040923 (http://vstbol.leidenuniv.nl/NHN/ Image/L0040923_HERB.jpg) has five fragments attached to the same sheet, one undeveloped branchlet with leaves, another one with male catkins at the beginning of anthesis, and three fragments with developed leaves without catkins. All fragments on this sheet belong to $S$. gracilistyla. There are two labels attached to the sheet with text: "Herb. Lugd. Batav. Salix gracilistyla Miq. Japonia, Buerger" and "Salix kawayanagi." The specimen P00761025 (http:// plants.jstor.org/stable/10.5555/al.ap.specimen. p00761025) has three fragments attached to the sheet: a fragment on the left with developed leaves, a fragment in the middle with juvenile leaves, and a fragment on the right with female catkins. All three fragments belong to $S$. gracilistyla. The label reads: "Herb. Lugd. Batav. Salix gracilistyla Miq. Japonia, Buerger.” The specimen P00761026 (http://plants.jstor.org/ stable/10.5555/al.ap.specimen.p00761026) has five fragments attached to the sheet: a fragment on the top right with juvenile leaves, a fragment in the middle with female catkins, and three other fragments with male catkins. All five fragments belong to $S$. gracilistyla. There are two labels attached to the sheet with text: "From the Herbarium of the Royal Gardens, Kew. Salix (527). Nagasaki, Japan, 1862. Collected by R. Oldham" and "Salix gracilistyla Miq. Japon." The fragments represent plants at different stages of development that suggests that they belong to the different gatherings. The fragment with female catkins in the middle of the herbarium sheet, P00761026, is selected here as the lectotype as it was preserved in better condition and corresponds best to the protologue.

Vernacular names. Chinese "Xi zhi liu"; Japanese "Neko-yanagi."

Classification. Salix gracilistyla belongs to the subgenus Vetrix Dumort., section Subviminales C. K. Schhneid. (Skvortsov, 1968, 1999). It is native to Japan, Korea, China, and Russia (Fang et al., 1999; Ohashi, 2000, 2001; Skvortsov, 1999).

Misapplication of scientific names takes place when "an author uses an existing name in a sense different to its original usage, or, more precisely, in a sense not including its type" (Turland, 2013). Type specimens should be studied to avoid ambiguity in name application. Seemen's type specimen of $S$. chaenomeloides (as $S$. glandulosa) was reported to be in the Berlin Herbarium which was destroyed by fire in 1943. An illustration of the species that was published by the author shortly after the original description of the species was published, is presented in Fig. 5 (Seemen, 1903). It depicts important morphological characteristics of the species.

\section{Ornamental Intraspecific Taxa}

Salix gracilistyla is a variable species as is obvious from numerous accepted infraspecific taxa-subspecies, varieties and forms (currently ranked at level of cultivars), as well as synonyms. It also hybridizes frequently with other species. Its ornamental varieties, forms, and hybrids are listed below. Also, a subset of cultivars, clones, and hybrids of $S$. gracilistyla frequently mislabeled as $S$. chaenomeloides and circulating throughout the North American trade is discussed.

\section{Cultivars}

High variability of $S$. gracilistyla resulted in the selection of five ornamental cultivars of this species or its hybrids. Among them are four cultivars - $S$. gracilistyla 'Melanostachys', S. gracilistyla 'Mt. Asama', S. gracilistyla 'Mt. Aso', and S. ×leucopithecia 'Lubber's Zwart'that are distinguished by a certain coloration of the catkins as a result of various colors of flower bracts. Flower bracts of $S$. gracilistyla are typically tricolored (the upper part is black, middle part is red, and base part of the bracts is pale yellowish green) and various aberrations of bract pigmentation were recorded in a few cultivars.

'Melanostachys' is derived from $S$. gracilistyla var. gracilistyla f. melanostachys which is currently treated at the rank of a cultivar.

Salix gracilistyla f. melanostachys (Makino) H. Ohashi, Sci. Rep. Tohoku Imp. Univ., Ser. 4, Biol. 40:343. $2001 \equiv S$. thunbergiana subsp. melanostachys Makino, Bot. Mag. (Tokyo). 18:141. $1904 \equiv S$. gracilistyla subsp. melanostachys (Makino) Makino, Bot. Mag. (Tokyo). $8: 175.1914 \equiv$ S. gracilistyla var. melanostachys (Makino) C.K. Schneid., Pl. Wilson. (C.S. Sargent). 3:164. $1916 \equiv$ S. melanostachys (Makino) Goerz, Salicac. Asiat. 1:21 (1931).

Type. Japan, Honshu, Tokyo Pref. (Prov. Musashi), Tokyo, Bot. Gard. Koishikawa cult S. Okubo 36 (male fl.), March. anno? (lectotype TUS-K, designated by A. Kimura (1981).

Etymology. Epithet 'melanostachys' is translated from Greek as "with black spike" referring to the dark reddish, nearly black catkins of this willow which was originally described from a cultivated plant in Japan.

Vernacular names. Japanese "Kuroyanagi," "Kuro-ome," "Kureneko."

A very unusual male cultivar of garden origin, with black, not-silky catkins, glabrous black bracts, and red anthers turning yellow at maturity. Leaves and branches are glabrous. It was cultivated as Salix 'Kurome' (in Japanese "kuro" means "black," "me" means "bud") in the Netherlands. This cultivar was disseminated to the United States from W. Hoogendoorn and Sons Nursery, Boskoop, Holland, since 1950 (Meyer, 1962). Ohashi (2001) listed it as a form with a comment on its distribution as cultivated rarely in gardens. Dirr (2009) suggested that this taxon is a hybrid. Makino (1904: p. 142) in his description of $S$. thunbergiana Blume ex Andersson subsp. melanostachys mentioned rudimentary pistil "linear, subbifid truncate at the top, $1 \mathrm{~mm}$ long"- teratological change that could be a result of either mutation or hybrid origin. Flower buds are not hardy below Zone 5 and this cultivar often doesn't flower in Vermont. This cultivar is common in trade, grown by 15 North American [Plant Information Online

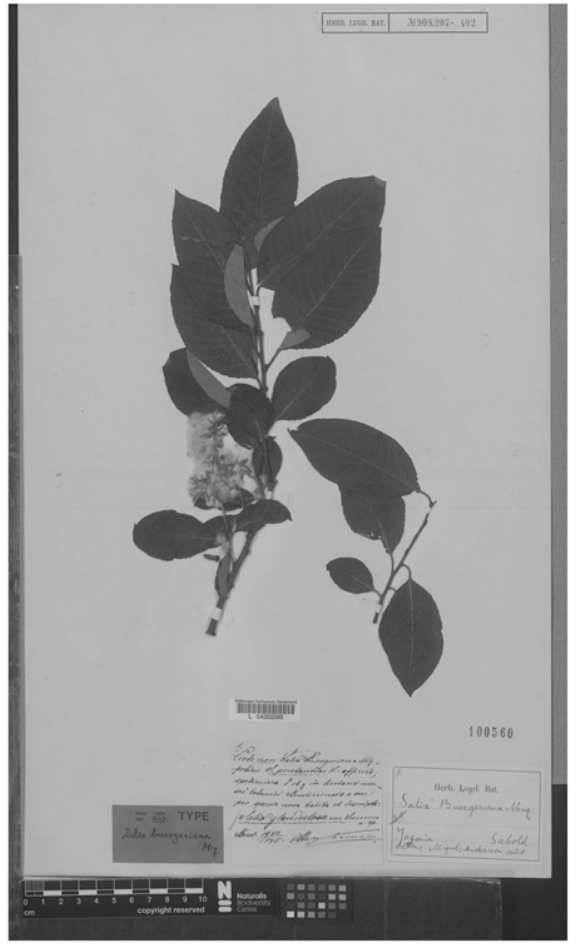

Fig. 3. Lectotype of Salix chaenomeloides Kimura (as Salix glandulosa Seemen, fragment with female catkins on the left). Reproduced with kind permission of the Naturalis Biodiversity Center, The Netherlands.

(University of Minnesota)] and 28 U.K. nurseries (Royal Horticultural Society Horticultural Database); in trade in the Netherlands (PlantScope, 2015). This selection was given awards by the U.K. Award of Garden Merit in 1976 and 2012 for ornamental characteristics and reliable performance in the garden.

'Mt. Asama'. No published description was found for this cultivar. Therefore, the name is not established in the Checklist for Cultivars of Salix L. (Willow) (Kuzovkina, 2015a). According to Pleasant Run Nursery (2015), emerging catkins have two-toned coloration of burgundy and silver. This nursery listed it as both salt and wet-site tolerant. It is listed under the common name "pinktinged pussy willow" in the Lazy S'S Farm Nursery (2015). This epithet often is listed erroneously as a cultivar of $S$. chaenomeloides. This is a male cultivar, according to the Forestfarm (2014) that is similar to 'Mt. Aso'. It was selected by a florist in Japan and named after the Japanese volcano "Asama." Nursery Forestfarm obtained this cultivar from Schwind, a Georgia Azalea breeder. Shu Suehiro noted that the common name "Asama-yanagi" was applied to the Japanese species Salix $\times$ koidzumii Kimura, but the cultivar Mt. Asama is not known in Japan and it could have originated in Europe or the United States (S. Suehiro, personal communication, Oct. 2015).

'Mt. Aso'. A male cultivar of $S$. gracilistyla selected in Japan by Dr. Tsuneshige Rokujo for the pink catkins and bluish foliage (Forestfarm, 2014). It was named after the largest volcano in Japan, Mount Aso. Forestfarm 

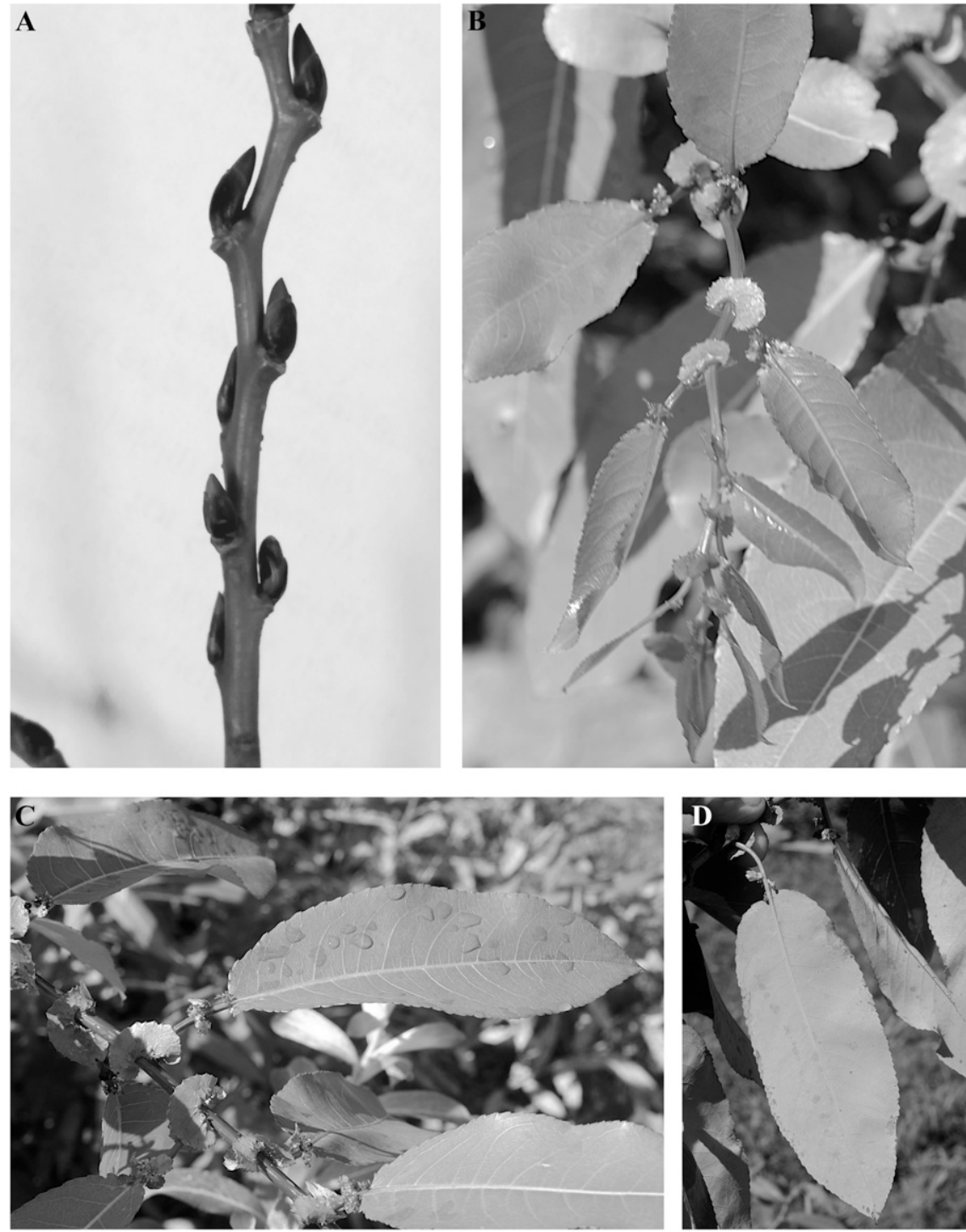

Fig. 4. Salix chaenomeloides: (A) branchlet fragment, (B) juvenile foliage, (C) stipules; (D) foliage lower side. Photos by M. Dodge.

obtained this cultivar from Mr. Schwind, a Georgia Azalea breeder. However, as with 'Mt. Asama', Shu Suehiro noted that this cultivar is not known in Japan (S. Suehiro, personal communication, Oct. 2015). Its branches can be used for Valentine's Day as an alternative to red roses (Fig. 1). According to Dirr (2009), a cultivar with abundant graywhite "caterpillar-like" catkins. The description is not very accurate as only old inflorescences turn into "long gray caterpillars." This epithet often is listed erroneously as a cultivar of $S$. chaenomeloides but is in fact $S$. gracilistyla.

'Pendula' is derived from S. gracilistyla var. gracilistyla f. pendula which is currently treated at the rank of a cultivar.

Salix gracilistyla f. pendula (Kimura) H. Ohashi, J. Jap. Bot. 75:24 (2000) $\equiv$ $S$. gracilistyla var. pendula Kimura, Bot. Mag. (Tokyo). 42:570. 1928.

Type. Japan, Honshu, Tochigi Pref. (Prov. Shimotsuke), Utsunomiya, cult. A. Kimura 1254 ๙ૈ, 22 Mar. 1927, §ิ (Holotype TUS-K, n.v.).
Vernacular name. Japanese "Shidarenekoyanagi."

A weeping selection from Japan (Ohashi, 2000). Although this cultivar is not common in trade, this name is listed among some gardening websites.

'Variegata' is derived from $S$. gracilistyla var. gracilistyla $\mathrm{f}$. variegata, which is currently treated at the rank of a cultivar. This cultivar is no longer offered by any nursery in North America and may not be present here.

S. gracilistyla var. gracilistyla f. variegata (Kimura) Kimura, Ecol. Rev. 13:200. 1953 三 $S$. gracilistyla var. variegata Kimura, Sci. Rep. Tohoku Imp. Univ., Ser. 4, Biol. 12:107. 1937. Type: Japan, Honshu, Miyagai Pref. (Prov. Rikuzen), Sendai, cult. A. Kimura 2409 (Holotype TUS-K, n.v.).

Vernacular name. Japanese "Fuirinekoyanagi."'

Variegation is stronger on shoots exposed to full sun (Dirr, 2009) and totally disappears if grown in dense shade (Dave Reed, personal communication, July 2015).

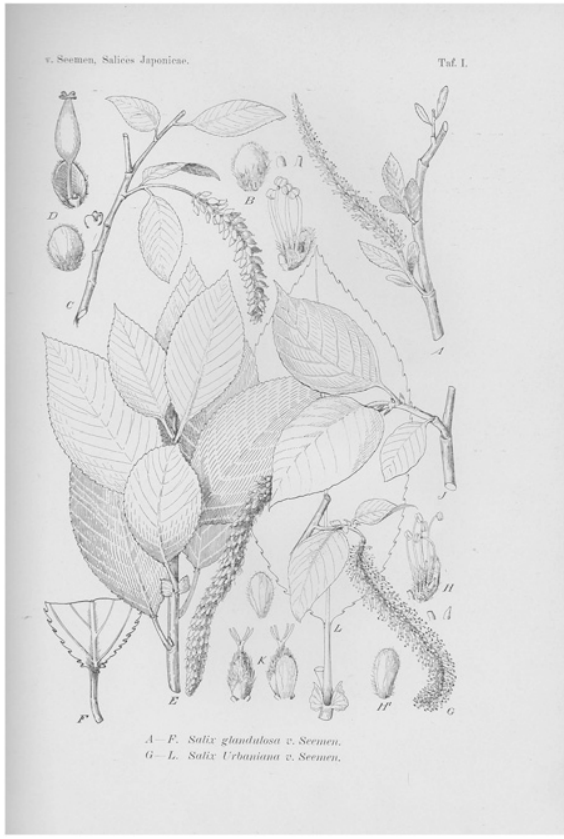

Fig. 5. An illustration of Salix chaenomeloides (as Salix glandulosa) by Seemen (1903). Reproduced with kind permission of the Board of Trustees of the Royal Botanic Gardens, Kew.

\section{Hybrid Species}

Salix $\times$ leucopithecia Kimura, Bot. Mag. (Tokyo). 40:11. 1926

Type. Japan. Honshu, Tokyo Pref. (Prov. Musashi), in sepulcris Somei, probe Tokyo. $A$. Kimura 59, 28 Mar. 1924, ô (holotype TI, n.v.)

$=S$. Xyoitiana Kimura, Bot. Mag. (Tokyo). 59:83. 1946.

Type. Japan, Hokkaido, Prov. Shiribeshi, in ripa fl. Hugoppe, prope Yoiti, I. Yamamoto 8167, 22 Apr. 1938, o (lectotype TUS-K n.v., designated by Kimura, 1981).

This willow was described originally by Kimura as a species with the name $S$. leucopithecia and treated later by Ohwi (1953) as a hybrid between $S$. bakko Kimura and $S$. gracilistyla Miq. Salix xyoitiana with parentage as $S$. hultenii Flod. var. angustifolia Kimura $\times S$. gracilistyla was synonymized with Salix Xleucopithecia (Ohashi, 2001) with parentage $S$. caprea L. $\times S$. 'The Hague' as both names, $S$. bakko and $S$. hultenii var. angustifolia, are synonyms of $S$. caprea.

This hybrid is cultivated for ornamental display in early spring. Chromosome numbers $n=19$ (Sinotô, 1929; Suda, 1958-1961). Japanese name "Furi-sode-yanagi" or "Furisode-yanagi" with parentage similar to the cultivar $S$. The Hague.

\section{Hybrid Cultivars}

Salix 'The Hague' (syn. S. hagensis Hort., nom. inval.; $S$. 'Hagensis' Hort.). A hybrid of $S$. caprea L. $\times$ S. gracilistyla Miq. (S. $\times$ leucopithecia Kimura), that is common in cultivation and was grown by S. G. A. Doorenbos at The Hague (Bean, 1981; 

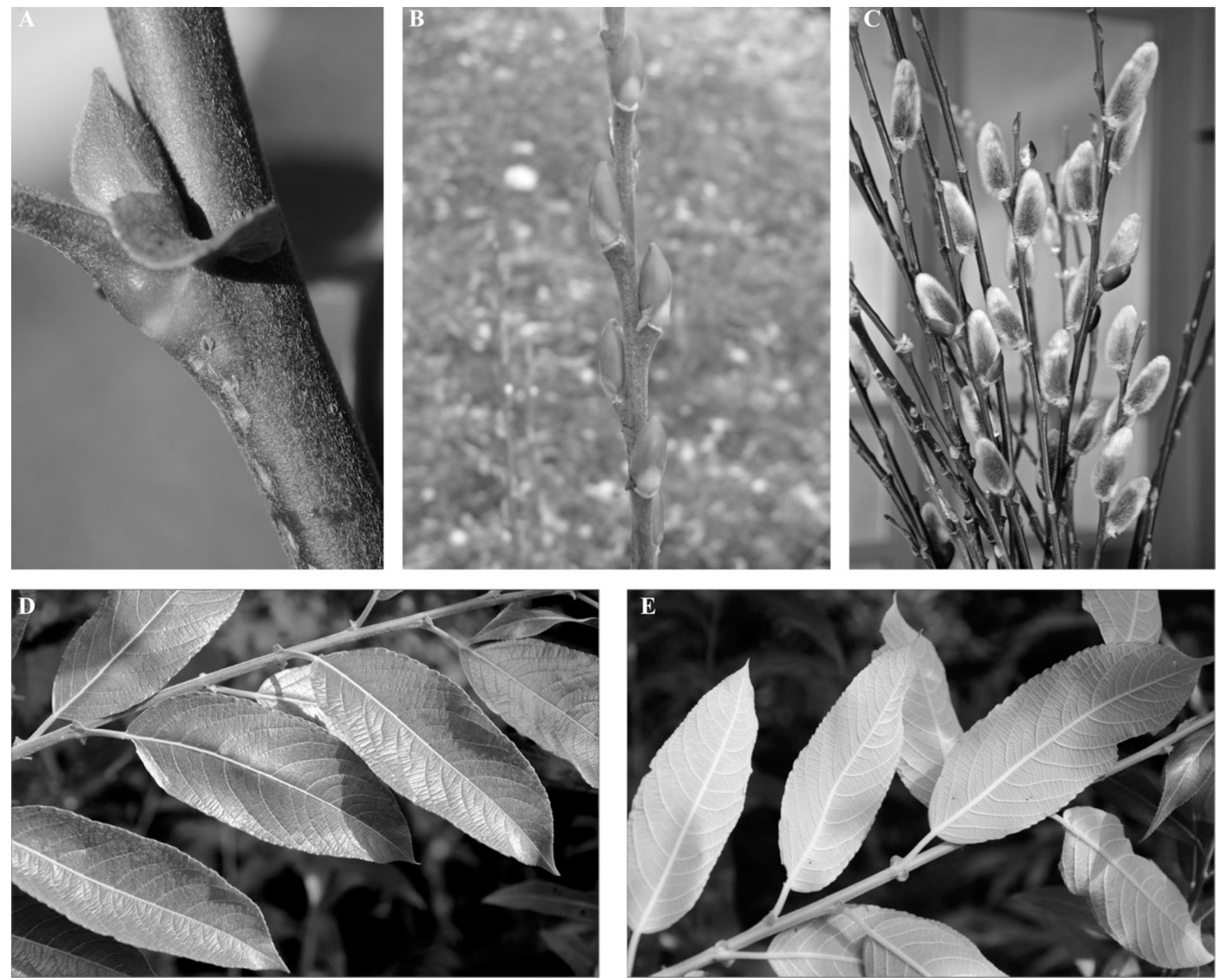

Fig. 6. Salix 'Winter Glory' generative buds in (A) September, (B) December, (C) aments after expansion before anthesis in February; branchlet fragments with foliage (D) upper and (E) lower surfaces. Photos by M. Dodge.

Walters et al., 1989). It is a vigorous female clone with thick densely pubescent, spreading stems. Leaves are oblong, acute or abruptly acuminate, $7-10 \mathrm{~cm}$ long, and $2-4 \mathrm{~cm}$ wide; glossy above and pubescent underneath with conspicuous acute stipules. It has numerous dense, very large catkins about $4-5 \mathrm{~cm}$ long that are very ornamental.

Salix 'Lubber's Zwart' (BLACK CAT ${ }^{\mathrm{TM}}$ ). A new cultivar of Salix with large and showy dark charcoal grey-black catkins that originated as sport mutation of a bud of the cultivar described in this article as $S$. 'Winter Glory', commonly cultivated under name $S$. chaenomeloides. Catkins are larger than in 'Melanostachys'. This cultivar has strong long stems that are suitable for floral cuttings. It was selected by Howard L. Lubbers (Tim Wood, personal communication, July 2015). It is listed in Spring Meadow Nursery (2015) as a cultivar of $S$. chaenomeloides registered under the Proven Winners ${ }^{\circledR}$ ColorChoice brand. Published in the Plant Patent US. Listed in the Community Plant Variety Office as registered by the Spring Meadow Nursery, Inc. (Canada) in 2014; published in the Plant
Varieties Journal. This epithet is should be listed as a cultivar of $S$. ×leucopithecia.

\section{New Cultivars}

The unique characteristics of plants that commonly cultivated in the U.S. trade under the erroneous name $S$. chaenomeloides, merit recognition as distinct cultivars called Salix 'Winter Glory' and Salix 'Rabbit's Foot'.

Salix 'Winter Glory'. Plants were purchased from Spring Meadow Nursery, Michigan, as $S$. chaenomeloides and cultivated in Vermont Willow Nursery since 2008. This cultivar is a possible hybrid of S. Xleucopithecia Kimura.

Etymology. Named for its long-lasting ornamental value in wintertime (Fig. 6). It is most attractive in late January to early March with its display of expanding inflorescences. Floral buds, differentiated during the previous summer begin to flush with color in August, becoming distinctly red in late fall and remain attractively red until budbreak in late winter. Occasional generative budburst takes place during fall even before leaf abscission has completed. Premature bud scale burst, can be attributed to mild weather conditions, frequently occurring on the adaxial side where the catkin appeared to protrude or push through the scale. This differs from the normal development of winter bud burst, when the bud scale splits along surfaces other than only the adaxial and/or detaches from the branch at the proximal end (Saska and Kuzovkina, 2010). Premature bud burst has never been observed in $S$. gracilistyla.

Salix 'Rabbit's Foot'. Plants were procured in 1999 from Klyn Nursery, Ohio, as $S$. chaenomeloides, and described in their catalog as with "catkin the size of a rabbit's foot." Plants were cultivated at the Chadwick Arboretum (Columbus, $\mathrm{OH}$ ) and then at the Research Farm of the University of Connecticut (Storrs, CT). Comparison of the catkins of this clone in March 2016 confirmed its identity with at the U.S. National Arboretum accession "NA 57189," which was introduced to the United States from Fujinami Nursery, Japan in 1985.

Etymology. Named because of its unique large lumpy catkins resembling a rabbit's foot not only by its size but by its structure. 

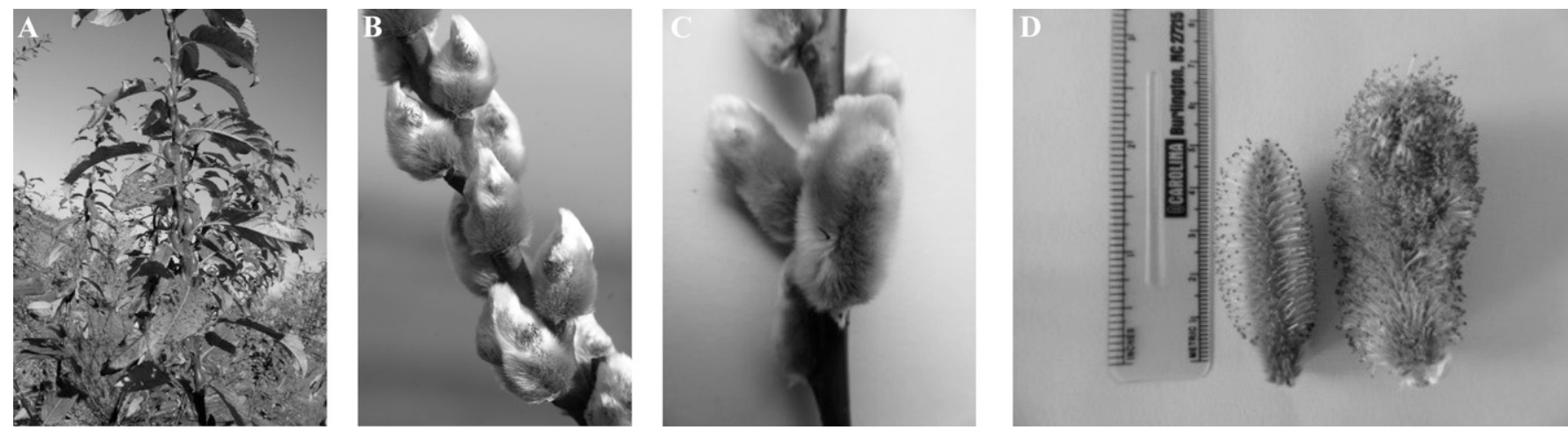

Fig. 7. Salix 'Rabbit's Foot': (A) branchlet fragments with glossy red buds; (B, C) close-up of aments; (D) staminate aments of (left) Salix gracilistyla and (right) $S$. 'Rabbit's Foot' during anthesis: $S$. gracilistyla ament is about $1.5 \mathrm{~cm}$ long at budbreak reaching $5 \mathrm{~cm}$ during anthesis; $S$. gracilistyla 'Rabbit's Foot' is about

$3 \mathrm{~cm}$ long at budbreak reaching $8 \mathrm{~cm}$ during anthesis. Photos by Y. Kuzovkina.

The unique characteristics of this unusual genotype, present in the U.S. trade, merit recognition as a distinct cultivar called Rabbit's Foot. This cultivar is very similar to $S$. 'Winter Glory' and is also a possible hybrid of $S$. ×leucopithecia Kimura. However, it produces large aments with aberrations in the form of lumps (Fig. 7).

The lumps are noticeable many months before anthesis as protrusions of the generative bud scales. They attract attention when aments form during the preceding year during late July-August, remaining visible during wintertime until the developing aments push off the bud scales and lumpy gray catkins appear. Flowers develop normally. Cross section of the bud reveals a branched axis of the catkin (Fig. 8). Branched or bifurcate catkins can be a sign of hybridity in willows. For example, a hybrid taxon $S$. xfragilis L. var. furcata Seringe ex Gaudin has bifurcate catkins (Meikle, 1984). Also, bifurcate catkins may result from atavism or a mutation. In fact, willows from the less advanced subgenus Longifoliae (Andersson) Argus have branched catkins.

There is evidence to suggest hybrid origin: both cultivars probably belong to the same hybrid taxon $-S$. ×leucopithecia $(S$. caprea $\times$ S. gracilistyla). This willow is thought to be cultivated in Japan (Walters et al., 1989), and probably, these selections originated in Japan. The Japanese name for $S$. ×leucopithecia is 'Akame-yanagi' ("akame" meaning "red shoot" or "red bud") (Shu Suehiro, personal communication, Oct. 2015), and the cultivar name Akame has been previously recorded without a description (Kuzovkina, 2015b). But our search did not reveal any details about this cultivar. Surprisingly, the Japanese name "Akame-yanagi" was applied to S. chaenomeloides causing very much confusion. The name 'Akame' has been linked to both species. Therefore, to limit the uncertainties, we propose to name commonly cultivated plants as new cultivars and avoid using cultivar epithet Akame.

Both cultivars, Winter Glory and Rabbit's Foot, are male, whereas the previously described 'The Hague' is a female selection and possibly another clone of $S$. ×leucopithecia Kimura. Catkins of both cultivars have
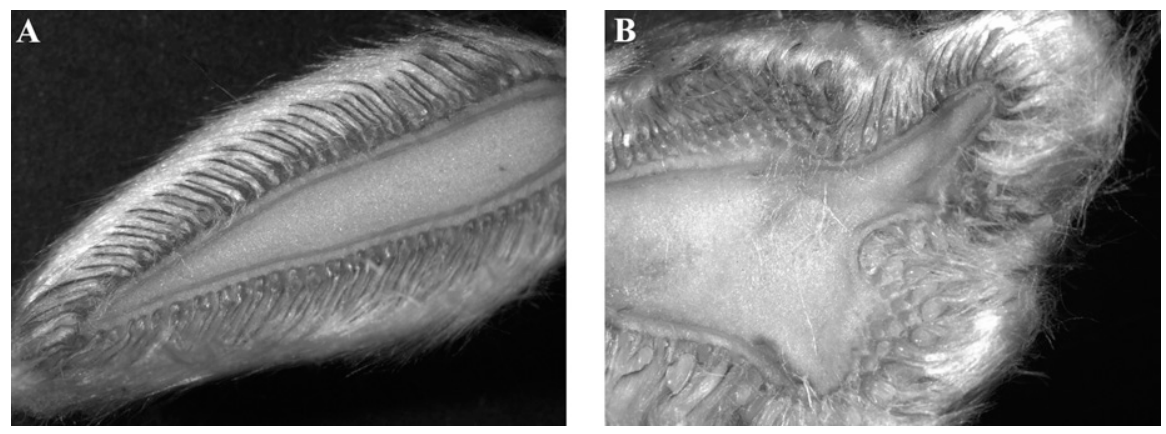

Fig. 8. Cross section of male aments of (left) Salix 'Winter Glory' and (right) Salix 'Rabbit's Foot'. Photos by C. Jones.
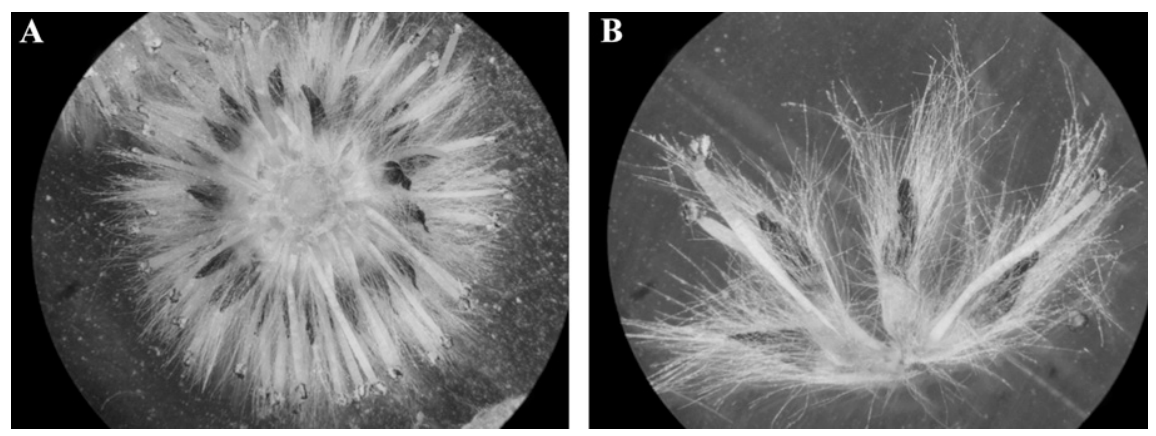

Fig. 9. A cross section of an inflorescence of Salix gracilistyla $(\mathbf{A})$ reveals the full fusion of filaments of two stamens that are subtended by a floral bract and appear as one in the picture (B). This prominent characteristic can be easily observed with a magnifying lens, making it a useful characteristic for species identification when comparing with Salix chaenomeloides which has two or more stamens with free filaments. Complete or partial fusion of the stamen's filaments is only observed in a few other willow species, but not in $S$. chaenomeloides. Photos by Y. Kuzovkina.

ornamental value and are frequently used for cut-stems. The subject of the hybrid origin of these cultivars requires further investigation using molecular markers. The DNA content of 'Rabbit's Foot' $(0.75 \mathrm{pg})$ is similar to $S$. gracilistyla $(0.72 \mathrm{pg})$.

Habit, size, and vegetative organs of both cultivars are very similar, but generative parts (catkins) differ. Both cultivars are deciduous, upright, somewhat arching shrubs. These selections are more vigorous than $S$. gracilistyla: this is typical for interspecific hybrids of willows to exhibit hybrid vigor, or heterosis, meaning that the offsprings are more robust than the parents (Kuzovkina et al., 2008). Both cultivars can reach $6 \mathrm{~m}$ high when left unpruned, or after coppicing produce long stems up to $3 \mathrm{~m}$ long.

The vegetative characters of 'Winter Glory' and 'Rabbit's Foot' are intermediate between $S$. caprea and S. gracilistyla. Branches are thicker and less pubescent than $S$. gracilistyla Miq. Floral buds are glabrescent (becoming glabrous in age with a few hairs remaining), glossy red, not pubescent as in S. gracilistyla Miq. or $S$. 'The Hague'. Leaves up to $10 \mathrm{~cm}$, dark green above and paler beneath, base cordate. Petioles 10-12 mm. 'Winter Glory' 
and 'Rabbit's Foot' have precocious development: their flowering takes place before leaves emerge. Flowers are borne in February-March on mostly erect catkins. The fully expanded inflorescences are 5-8 cm long. Stamen filaments are connate. Both cultivars have long-lasting ornamental value in winter and springtime.

\section{Conclusions}

The most practical and easily noticeable distinguishing characteristics of S. gracilistyla and $S$. chaenomeloides that can be used for correct identification include bud scales (united vs. imbricate), leaf surface (sericeous vs. glabrous), presence of petiole glands in S. chaenomeloides, flowering phenology (precocious vs. coetaneous), aments (densely vs. loosely flowered), number of nectaries ( 1 vs. 2 or connate to a ring), number of stamens ( 2 connate vs. (3)4-5 free), anthers (reddish at the beginning of anthesis vs. yellow), and ovary (sessile vs. stipulate). Regarding ornamental value, the catkins of $S$. chaenomeloides are long, yellowish-green and inconspicuous among the developing leaves. Aments of S. gracilistyla are whitishgray because of dense hair of the bracts (exhibiting "pussy willow" effect); large oval and very ornamental when developing in late winter or early spring before the leaf emergence.

Distinctive features that can be easily observed by nursery professionals examining the stock plants throughout most of the year (from September until February-March) include the size of generative buds that are large in S. gracilistyla and its cultivars, wheras in $S$. chaenomeloides they are small and not as easily distinguishable from vegetative buds. In spring the number of filaments (Fig. 9) and red color of anthers during the early stage of anthesis confirm that the specimen belongs to $S$. gracilistyla rather than $S$. chaenomeloides.

Recommendation to nursery professionals. Botanically accurate representations of nursery stock are an important goal for the green industry. However, when familiar names are replaced, consumers may not recognize products offered under new names. Changes of plant names could negatively affect the marketability of products. It is recommended that both names - " $S$. 'Winter Glory' or $S$. 'Rabbit's Foot' (previously sold as $S$. chaenomeloides)" or " $S$. 'Winter Glory' or $S$. 'Rabbit's Foot' [S. chaenomeloides]"-be relisted in catalogs during a transition period to allow for a gradual change without adversely affecting sales. (Misapplied names should be mentioned in square brackets at the end of the list of synonyms according to the Melbourne Code (McNeill et al., 2012).

\section{Literature Cited}

Argus, G.W. 2010. Salix, p. 23-162. In: Flora of North America Editorial Committee (eds.). Flora of North America North of Mexico. Vol. 7. Oxford University Press, New York and Oxford. Armitage, A.M. and M.A. Dirr. 1995. Influence of spacing on yield of Buddleia and Salix grown as cut flowers and stems. J. Environ. Hort. 13:176-177.

Bailey, L.H. 1924. Manual of cultivated plants: A flora for the identification of the most common or significant species of plants grown in the continental United States and Canada, for food, ornament, utility, and general interest, both in the open and under glass. Macmillan, New York.

Bailey, L.H. and E.Z. Bailey. 1976. Hortus third: A concise dictionary of plants cultivated in the United States and Canada. Revised and expanded by the staff of the Liberty Hyde Bailey Hortorium, Cornell Univ. Macmillan, New York.

Bean, W.J. 1981. Trees and shrubs hardy in the British Isles, p. 246-312. 8th ed. Revised by D.L. Clarke. John Murray, London, UK.

Dickmann, D. and Y.A. Kuzovkina. 2014. Poplars and Willows in the World, p. 8-91. In: J.G. Isebrands and J. Richardson (eds.). Poplars and Willows: Trees for Society and the Environment, FAO UN and CABI, Boston, MA.

Dirr, M.A. 1998. Manual of woody landscape plants: Their identification, ornamental characteristics culture, propagation and uses. 5th ed. Stipes Publishing, Champaign, IL.

Dirr, M.A. 2009. Manual of woody landscape plants: Their identification, ornamental characteristics culture, propagation and uses. 6th ed. Stipes Publishing, Champaign, IL.

Fang, Z-F., S-D. Zhao, and A.K. Skvortsov. 1999. Salicaceae, p. 139-274. In: Z-Y. Wu and P.H Raven (eds.). 1994+. Flora of China. 16+ vols. Vol. 4. Science Press, Beijing, China and Missouri Botanical Garden Press, St. Louis, MO.

Forestfarm. 2014. Salix. 20 Sept. 2014. <https:// www.forestfarm.com>.

Greer, L. and J. Dole. 2008. Woody cut stems for growers and florists: Production and postharvest handling of branches for flowers, fruit, and foliage. 1st ed. Timber Press, Portland, OR.

Hillier, J.G. 2014. The Hillier manual of trees and shrubs. Royal Horticultural Society, London, UK.

Kimura, A. 1981. List of the type specimens in the herbaria of Japan. Salicaceae. A working group on determination of types and authentic specimens of vascular plants, c/o Herbarium, Dept. Botany, Kyoto University, Kyoto, Japan.

Krussmann, G. 1978. Hanbuch der laubegeholze (in German). Paul Parey Verlag, Berlin, Germany.

Krussman, G. 1984. Manual of cultivated broadleaved trees and shrubs. Timber Press, Beaverton, OR.

Kuzovkina, Y.A. 2015a. Compilation of the checklist for cultivars of Salix L. (Willow). HortScience 50:1608-1609.

Kuzovkina, Y.A. 2015b. Checklist for cultivars of Salix L. (willow). International Poplar Commission. 17 Jan. 2016. <http://www.fao.org/forestry/ 44058-0370ab0c9786d954da03a15a8dd4721ed. pdf $>$.

Kuzovkina, Y.A., M. Weih, M. Abalos Romero, J. Charles, S. Hurst, I. McIvor, A. Karp, S. Trybush, M. Labrecque, T. Teodorescu, N.B. Singh, L. Smart, and T. Volk. 2008. Salix: Botany and global horticulture. Hort. Rev. 34:447-489.

Lazy S'S Farm Nursery. 2015. Salix. 17 Sept. 2015. <http://www.lazyssfarm.com>.

Makino, T. 1904. Observations on the flora of Japan. Bot. Mag. (Tokyo) 18:129-131.

McNeill, J., F.R. Barrie, W.R. Buck, V. Demoulin, W. Greuter, D.L. Hawksworth, P.S. Herendeen, S. Knapp, K. Marhold, J. Prado, W.F. Prud'homme van Reine, G.F. Smith, J.H. Wiersema, and N.J. Turland (eds.). 2012. International Code of Nomenclature for algae, fungi, and plants
(Melbourne Code): Adopted by the Eighteenth International Botanical Congress Melbourne, Australia, July 2011. Regnum Vegetabile 154, Koeltz Scientific Books, Konigstein, Germany.

Meikle, R.D. 1984. Willows and poplars of Great Britain and Ireland. Botanical Society of the British Isles, London, UK.

Meyer, F.G. 1962. Identification of some willow (Salix) cultivars from Japan. Baileya 19:19-20.

Newsholme, C. 1992. Willows: The genus Salix. B.T. Batsford Ltd., London, UK.

Ohashi, H. 2000. A systematic enumeration of Japanese Salix (Salicaceae). J. Jpn. Bot. 75:1-41.

Ohashi, H. 2001. Salicaceae of Japan. Science reports of the Tohoku University, 4th series. Biology (Basel) 40:269-396.

Ohwi, J. 1953. Flora of Japan. Shibundo. Tokyo (in Japanese).

Ohwi, J. 1965. Flora of Japan. Smithsonian Institution, Washington, D.C.

Plant Information Online database. 2015. 17 Jan. 2016. <http://plantinfo.umn.edu/>.

PlantScope. 2015. Salix. 17 Sept. 2015. <www. plantscope.nl>.

Pleasant Run Nursery. 2015. Salix. 17 Sept. 2015. $<$ http://www.pleasantrunnursery.com>

Rehder, A. 1927. Manual of cultivated trees and shrubs. Macmillan, New York.

Rehder, A. 1940. Manual of cultivated trees and shrubs. 2nd ed. Macmillan, New York.

Rehder, A. 1949. Bibliography of cultivated trees and shrubs. Arnold Arboretum of Harvard University, Jamaica Plain, MA.

Royal Horticultural Society Plant Finder. 2015. Salix. 17 Sept. 2015. <https://www.rhs.org. $\mathrm{uk} />$.

Saska, M. and Y.A. Kuzovkina. 2010. Phenological stages of willow (Salix). Ann. Appl. Biol. 156(3):431-437.

Saska, M., Y.A. Kuzovkina, and R. Ricard. 2010. North American willow cut-stem growers: A survey of the business identities, production practices and prospective for the crop. HortTechnology 20:351-356.

Seemen, O. von. 1903. Salices Japonicae. Gebrüder Borntraeger, Leipzig, Germany.

Sinotô, Y. 1929. Chromosome studies in some dioecious plants with special reference to the allosomes. Cytologia (Tokyo) 1:109-118.

Skvortsov, A.K. 1968. Willows of the USSR. A taxonomic and geographic revision (in Russian). Nauka Publishers, Moscow, Russia.

Skvortsov, A.K. 1999. Willows of Russia and adjacent countries. Taxonomical and Geographical Revision (English translation of 1968 Russian edition). University of Joensuu, Joensuu, Finland.

Spring Meadow Nursery. 2015. Salix. 17 Sept. 2015. $<$ http://springmeadownursery.com/home $>$.

Suda, Y. 1958-1961. The number of chromosomes in some Japanese salicaceous plants. Sci. Rep. Tohoku Univ. Ser. IV Biol. 29:413-430.

Thiers, B. (ed.). 2013. Index Herbariorum: A global directory of public herbaria and associated staff. 30 Nov. 2015. <http://sweetgum.nybg.org/ih/>.

Turland, N. 2013. The code decoded. Regnum Veg. 155. Koeltz Scientific Books, Oberreifenberg, Germany.

Uronen, T. 2004. Pajujen suku (Salix): Alasuku Salix rantojen puut eli halavat, salavat ja jokipaju. Sorbifolia 35(1):16-23.

Walters, S.M., et al. (eds.). 1989. The European garden flora: A manual for the identification of plants cultivated in Europe, both out-of-doors and under glass. Vol. III. Cambridge University Press, Cambridge, New York, New Rochelle, Melbourne, Sydney. 